\title{
Prevalence of genotypes and subtypes of hepatitis $B$ viruses in Bangladeshi population
}

\author{
Md. Arifur Rahman 1,3, Farzana Hakim', Mamun Ahmed², Chowdhury Rafiqul Ahsan', Jamalun Nessa' \\ and Mahmuda Yasmin ${ }^{1 *}$
}

\begin{abstract}
The genetic variability of hepatitis B virus (HBV) represents a challenge for the sensitivity of immunologic and molecular based assays. Based on sequence divergences in the entire genome of $>8 \%$, HBV genomes have been classified into ten genotypes designated as A to J. The aim of this study was to determine HBV genotypes and subtype in samples of HBV infected patients in Bangladesh. The sera samples were collected from chronically infected HBV patients. At first the DNA positive HBV samples were screened by EIA in our laboratory and the 1063 bp region of surface gene was amplified, sequenced and genotyped by sequence analysis. The same sequences were also used for subtypes and mutational analyses. After that, genotyping was also carried out by nested PCR using genotype specific primers in the same region of HBV surface gene. A total of 39 samples were sequencing to find out the genotypes and subtypes. It was found that the prevalent genotype was genotype C (subgenotype C1) which accounted for $48.7 \%$. The other genotypes found were genotype A (23.1\%) and genotype D (28.2\%). Predominant subtypes in Bangladesh were $\operatorname{adr}(41 \%)$ followed by subtype adw2 (28.2 \%), ayw3 (25.6\%), and others. Additionally, genotyping was also done by nested PCR using type-specific primers. In this method, out of 17 samples 6 were found to be genotype $C$, followed by genotype $D$ ( 4 of 17) and genotype A (3 of 17). In PCR-based genotyping system we also observed the mix genotypes; 3 samples contained both genotype $A$ and $D$, and 2 samples contained both $C$ and $D$. The genetic diversity of HBV and distribution of its genotypes and subtypes amongst Bangladeshi population were done in this study, which will help us to provide information regarding circulating genotypes in this region and also help physicians to prescribe proper antiviral/interferon therapy.
\end{abstract}

Keywords: Genotype, Subtype, Mutation, HBsAg

\section{Background}

Hepatitis B virus (HBV) infection is one of the most widespread viral infections in humans with a spectrum of liver diseases ranging from asymptomatic state to serious public health problem (Lee 1997). About 2 billion people have been infected worldwide with an estimated 300-350 million carrier, $40 \%$ of whom may develop complicated clinical sequelae, including liver cirrhosis (LC), liver cancer, and hepatocellular carcinoma (HCC) (Yang et al. 2008). According to WHO, approximately 600,000 deaths occur worldwide annually due to chronic complication of

\footnotetext{
*Correspondence: yasmin@du.ac.bd

${ }^{1}$ Department of Microbiology, University of Dhaka, Dhaka 1000,

Bangladesh

Full list of author information is available at the end of the article
}

HBV associated liver disease (WHO 2008). The outcome of HBV infection depends on a wide variety of factors, such as, host's immune response, rate of virus replication and probably genetic variability of the virus (Huy et al. 2003).

Prior to definition of genotypes, HBV were categorized as subtypes based on serological differences (Norder et al. 1992), based on immune reaction by amino acid pattern at specific location of "a" determinant which leads to the nine different subtypes designating $a d w 2, a d w 4, a d r \mathrm{q}+$, adrq-, ayw1, ayw2, ayw3, ayw4 and ayr. In 2002, a new subtype $a d w 3$ has been described (Norder et al. 1992; Magnius and Norder 1995). Their distributions within the genomic groups have shown to be restricted. Subtype $a d w 2$ is found to genotype $\mathrm{A}, \mathrm{B}$ and $\mathrm{C}$ whereas; $a d w 4$ is only circulated on genotypes E and F (Norder et al. 1992).

\section{贷 Springer}


On the other hand, ayw2 and ayw3 both are associated with group D. However, ayw1 has been isolated from genotypes A and B (Norder et al. 1992). The HBV isolates expressing $a d r / a y r$ is only been found in genotype $\mathrm{C}$ (Norder et al. 1992).

Genotypically, HBV genomes have been classified according to their genetic variability ( $>8 \%$ for whole genome) into ten major genotypes designating A to J (Magnius and Norder 1995; Cao 2009; Yu et al. 2010; Tatematsu et al. 2009). The genetic diversity occurs due to the replication error of the virus during their multiplication. Though HBV contains DNA molecules as their genetic material, it replicates via an RNA intermediate. That is why error rate of this virus is higher (approximately $>2 \times 10^{4}$ base substitutions/site/year) as the proofreading activity of the viral polymerase is lacking (Buti et al. 2005).

HBV genotypes show a distinct geographic and ethnic distribution. Genotype A is the most commonly distributed globally and is leading genotype in Europe, North America, Africa and India, whereas B and C are the dominant genotypes in East and Southeast Asia (Norder et al. 1993; Kao and Chen 2006). Genotype D is prevailing in the Middle East and Mediterranean region and India, and genotype $\mathrm{E}$ is commonly found in sub-Saharan Africa (Mulders et al. 2004; Kramvis et al. 2005) along with some other continents (Singh et al. 2009). Outside the Central and South America, genotypes $\mathrm{F}$ and $\mathrm{H}$ are rarely found (Alvarado Mora et al. 2011; Devesa et al. 2008), and Genotype G is circulating among the people of USA, Mexico, France and Germany (Tanwar and Dusheiko 2012). This genotype is normally present as a co-infection with other HBV genotypes, most commonly with genotype A. The genotypes I has been detected in Laos, Vietnam and China (Phung et al. 2010; Olinger et al. 2008), while the newest genotype; J was identified in the Ryukyu Islands in Japan (Tatematsu et al. 2009). The most commonly found genotypes in Asia are B and $C$ with the exception of India where the genotype A and D are most prevalent (Cao 2009; Schaefer 2007; Acharya et al. 2006).

In this study, we attempted to find out the prevalence of HBV genotypes, subgenotypes and subtypes among the Bangladeshi population. The study also focused on clarifying the origin of these genotypes as well as some significant mutation on the S protein gene of HBV. Nucleotide substitution of these sites (mainly small $\mathrm{S}$ portion) may lead to changed amino acid sequences causing dramatic changes in viral life cycle.

\section{Methods}

\section{Patients}

Sera were collected from 50 cases chronically infected by HBV who attended one of the largest hospitals in the
Dhaka city which provide services to the patients coming from different parts of the country. This hospital is well known for its diagnostic services and is therefore chosen by many physicians and patients. The samples were collected between the year 2009 and 2011, and were tested previously in the hospital laboratory by commercial real-time PCR (COBAS TaqManTM 48 Analyzer, Roche Diagnostics, Mannheim, Germany) to determine the HBV DNA level. The patients who cleared HBsAg within 6 months of onset of infection were excluded from this study as per physicians' suggestion (Due to the possibility of acute infection). The age of the patients included in this study were 11-65 years with a mean age of 29.8 years. Patients' sera were collected and stored at $-20{ }^{\circ} \mathrm{C}$ until the experiment was done. After that, all sera samples were tested for HBsAg by enzyme immune assay (EIA) using commercial EIA kit (ETI-MAK-4, DiaSorin, Italy). The study was approved by Institutional ethical committee and all subjects gave their consent to participate in this study.

\section{DNA extraction and PCR amplification}

HBV DNA was extracted from $200 \mu \mathrm{l}$ of all sera samples regardless of EIA result, using a QIAamp DNA blood mini kit (Qiagen, Chatswort, Calif Germany) according to the manufacture's instruction. A length of $1063 \mathrm{bp}$ surface gene spanning from nt 2823-704 was amplified using primer pairs P1 (5'-TCA CCA TAT TCT TGG GAA CAA GA-3') and S1-2 (5'-CGA ACC ACT GAA CAA ATG GC-3'). The reaction was carried out in $50 \mu \mathrm{l}$ reaction volumes containing $200 \mathrm{pmol}$ of each primer, $2.5 \mathrm{mM}$ of each of the four dNTPs, $2.5 \mathrm{mM} \mathrm{MgCl}_{2}, 1.25 \mathrm{U}$ of Taq DNA polymerase and $1 \times$ PCR buffer. The thermocycler was programmed as $95^{\circ} \mathrm{C}$ for $10 \mathrm{~min}$, followed by $94{ }^{\circ} \mathrm{C}$ for $20 \mathrm{~s}, 55{ }^{\circ} \mathrm{C}$ for $20 \mathrm{~s}, 72{ }^{\circ} \mathrm{C}$ for $1 \mathrm{~min}$ and an additional $72{ }^{\circ} \mathrm{C}$ for $7 \mathrm{~min}$. The resulting PCR product was detected by gel electrophoresis on a $0.8 \%$ agarose gel. Genotype of HBV was determined by sequencing of amplified DNA and also by using genotype-specific PCR amplification.

\section{Genotyping using type specific primers}

This is a rapid genotyping system proposed by Naito et al. (2001). The 1063 bp product generated by amplification with P1and S1-2 primers was used as template in this reaction. To determine the genotype (A to F), eight additional type specific primers were used. The same method was followed as well as same primers (Additional file 1) were used as proposed by Naito et al. in 2001. Here, two reaction mixtures were prepared, separated as mix $A$ (for genotype A, B and C) and mix B (for genotype D, E and $F$ ). The reaction condition was as same as the first round reaction with a few changes in case of annealing 
temperature of primers. Genotypes were determined by their distinct pattern of band on agarose gel as genotype A (68 bp), B (281 bp), C (122 bp) for the mix A and D (119 bp), E (167 bp), and F (97 bp).

\section{Genotype determination by direct DNA sequence}

The PCR products were purified using Microcon (Millipore) PCR purification kit according to the manufacture's procedure, and the concentration of DNA was measured by nano-drop spectrophotometer. Each sample was sequenced by both forward and reverse primers. After ethanol precipitation, the purified PCR products were subjected to sequencing in the ABI prism 3130 Genetic analyzer (ABI prism, USA).

\section{Sequence analysis}

Sequences received from ABI prism analyzer were 'abi' file format. The sequences were edited with Chromas 3.3 software (Tecnhnelysium Pty Ltd) by comparing with same DNA fragment of published sequences on GenBank and were saved as 'scf' file format. The contigs were assembled by DNASTAR's Lasergene sequence analysis software (Burland 2000). The edited sequences were saved as FASTA file format for further analysis. A phylogenetic analysis was done using reference sequences from various countries retrieved from the international DNA data base (Additional file 2). Phylogenetic analysis of $950 \mathrm{bp}$ fragment of large $\mathrm{S}$ gene using MEGA, version 5 (Tamura et al. 2007), was the basis for HBV genotyping implying p-distance substitution model with the neighbor joining method. The reliability of different phylogenetic groupings was evaluated using the bootstrap test (1000 bootstrap replications).

\section{Genotyping by NCBI genotyping tools}

It is easy and rapid method and can be achieved using BLAST (basic local alignment search tool), where a query sequence was compared to a set of reference sequences of known genotypes. The query sequence was broken into segments for comparison to the reference so that the mosaic organization of recombinant sequences could be revealed (Reuman et al. 2010).

\section{Prediction of HBV subtypes}

DNA sequences were translated to proteins using internet software expaXy translation tools. The best and high scoring matches with HBV proteins were aligned with CLUSTAL W software program (Larkin et al. 2007), and the alignment was edited by BioEdit sequence alignment program (Hall 1999). Amino acid alterations within the small $\mathrm{S}$ portion of surface protein were determined by comparing with reference sequences available in data bank (Additional file 2). HBV subtypes were determined according to the presence of amino acid residues at specific locations on surface proteins. The subtypes were determined by analyzing amino acid positions, like at position 122 (Lys/Arg for subtype d/y determinant), 160 (Lys/Arg for w/r), and 127 (Pro/Thr/Leu-Ile for w1-2/w3/ w4) (Magnius and Norder 1995). Amino acid positions 134 and 159 were used to discriminate between type ayw 1 and ayw 2 .

\section{Accession numbers}

After analyzing the HBV sequences, we submitted our sequences to GenBank and we got an accession number for each sequence. We had total 39 sequences and the accession numbers are sequentially organized from KF498977 to KF499015.

\section{Results}

The 50 patients, included in this study, diagnosed as chronic carrier by physicians. The DNA levels were previously measured for all patients using real time PCR (HBV TaqMan, Roche), had a value ranged from $3.1 \times 10^{4}$ to $1.2 \times 10^{12}$ copies $/ \mathrm{ml}$. However, in EIA test we found 47 of them were HBsAg positive and 3 were negative. When amplified with P1/S1-2 primers, a1063 bp of amplified PCR product was revealed on agarose gel electrophoresis (Fig. 1a). After that, 39 of 50 PCR positive samples were selected from for direct sequencing. Among them 38 were HBsAg positive and one was HBsAg negative (Additional file 3). The samples showing weak bands or multiple bands were excluded from sequencing as well as from others study. Two of the three HBsAg negative samples were also excluded due to showing weak bands. Next, the samples were subjected to nested PCR using genotype specific primers.

\section{Genotyping and sub genotyping by using DNA sequence}

Genotyping of $39 \mathrm{HBV}$ isolates (Accession number; [GenBank: KF498977-KF499015]) were determined by constructing phylogenetic tree (Fig. 2). The test sequences were grouped with the reference sequences (Additional file 2) according to their genotypes. The predominant genotypes were genotypes C (48.7\%), D $(28.2 \%)$ and A (23.1\%). The genotypes of these sequences were also determined by NCBI genotyping tools which gave complete fidelity with the phylogenetic result.

During the determination of subgenotypes, we found only single subgenotype within the genomic group $C$ and genotype $\mathrm{A}$. These were $\mathrm{C} 1$ and $\mathrm{A} 1$ respectively. However, in case of genotype $\mathrm{D}$, multiple subgenotypes were found (Table 1). These were D1, D2, D3 and D5. 


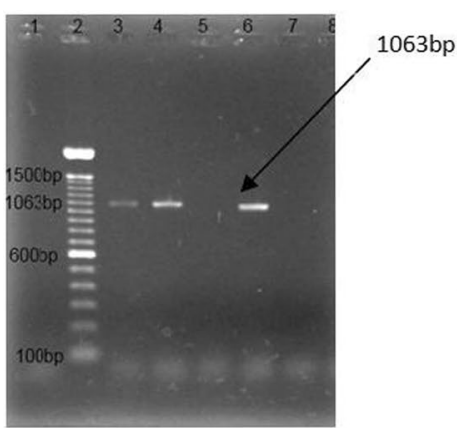

a

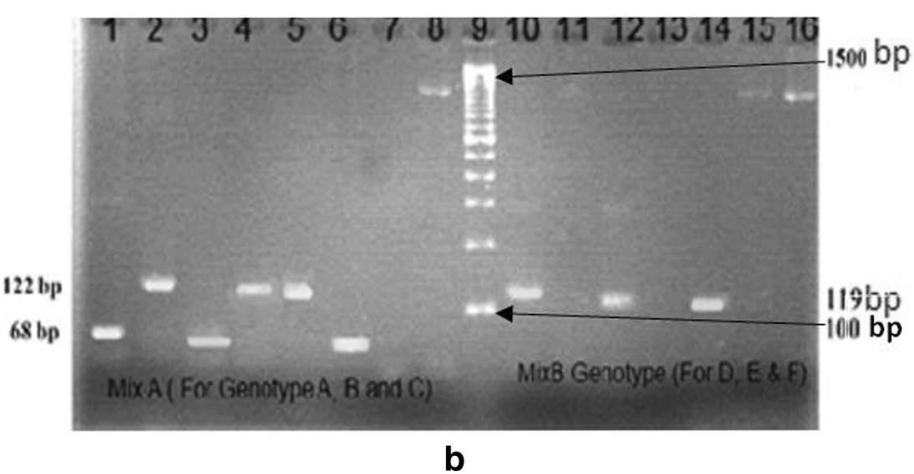

b

Fig. 1 Agarose gel electrophoresis. a Showing PCR positive band size of 1063 bp of HBV Large $S$ gene. b The typical electrophoresis patterns using type specific primer of different HBV genotypes (Genotype, A-68 bp; C-122 bp; D-119 bp). In this figure, lane 1, 2, 3, 4, 5 and 6 showed the band for the sample accession number of KF499015, KF498982, KF498984, KF498996, KF499007 and KF498990 respectively. Lane 7 was mix A negative control whereas lane 15 was negative control for mix B. The same samples were loaded sequentially from lane $10-14$ and lane 16 contains KF498990. (The figure was cropped to minimize the figure size and included the numerical values as well as labels)

\section{Genotyping by genotype-specific primers}

In this method, the genotypes were determined by observing the genotype specific band on the agarose gel electrophoresis. The samples giving 1063 bp PCR product in first round PCR by $\mathrm{P} 1 / \mathrm{S}-2$ primers were subjected to multiplex PCR using type-specific primers (Fig. 1b). Here, 17 of 39 samples were successfully analyzed, rest of the samples did not produce right sized product or no product at all. Three of 17 samples were detected as genotype A, 6 were genotype $C$ and 4 were genotype $D$. However, for some cases we found more than one band for a single sample, implied that those patients carried multiple genotypes or mix infection. In Fig. 1b, lane 1 and lane 10 showed band from single sample (KF499015) which indicates, this sample carried both genotype A (68 bp on mix A) and D (119 bp in mix B). Likewise, KF499007 contained both genotype C and D (122 bp band in mix A in lane 5 and 119 bp band in mix B in lane 14). In our experiment, we found mixed genotypes $A$ and $D$ in 3 samples as well as genotype $C$ and $D$ in 2 samples.

\section{Distribution of subtype}

Amino acid substitutions in residues related to subtype specificity were determined for all 39 samples. The predominant subtypes we found in our experiment were, $a d r$ (41\%), adw2 (28.2 \%), ayw2 (5.1\%) and ayw3 (25.6\%) (Table 2).

\section{Amino acid substitutions in surface protein}

Mutation on surface gene lead to altered conformation of the protein in several ways. In our study we have detected several amino acid substitutions on $\mathrm{S}$ region in some isolates. Four of the 39 isolates showed amino acid substitutions in a total of 5 positions. Sample 2-P2 [GenBank:
KF498978] showed two amino acid substitutions at G119R and P120A, HBV-350 [GenBank: KF498986] at G145R, HBV-418 [GenBank: KF498987] at C149 W and HBV-532 [GenBank: KF498998] at S117I; located within the major hydrophilic region (MHR) of the $S$ gene and few are within the 'a' determinant. The correlation between the amino acid alteration and course of disease pattern had not been examined in this study.

\section{Discussion}

In recent years viral hepatitis is a major public health problem worldwide. As with other Asian countries, Bangladesh is also hyper-endemic for HBV related liver disease, with seroprevalence of HBsAg is 6-7 \% (Rahman et al. 2007). However, data on genotype or subtype of HBV are not sufficient. Some previous studies were conducted based on the serological assay where they have only shown the sero-prevalence HBV in Bangladesh (Rahman et al. 2007; Zaki et al. 2003). In this study, we have tried to find out the distribution of genotypes and subtypes in Bangladesh, because, genotyping and subtyping of HBV has its great implementation as HBV have their characteristic geographical distribution. Determination of genotypes and subtypes also has clinical as well as therapeutic importance as vaccine development, drug selection, and mutant identification (Shi 2012). In Bangladesh, we have provided the first molecular study on HBV. We sequenced and analyzed the large surface gene of HBV (spanning from pre-S1, pre-S2 and most part of small surface gene) and the genotypes were determined by phylogenetic tree (by comparing with reference strains of Additional file 2) using Mega5 software (Tamura et al. 2007). In this study we also determine HBV genotypes by NCBI genotyping tools. This study showed that the 


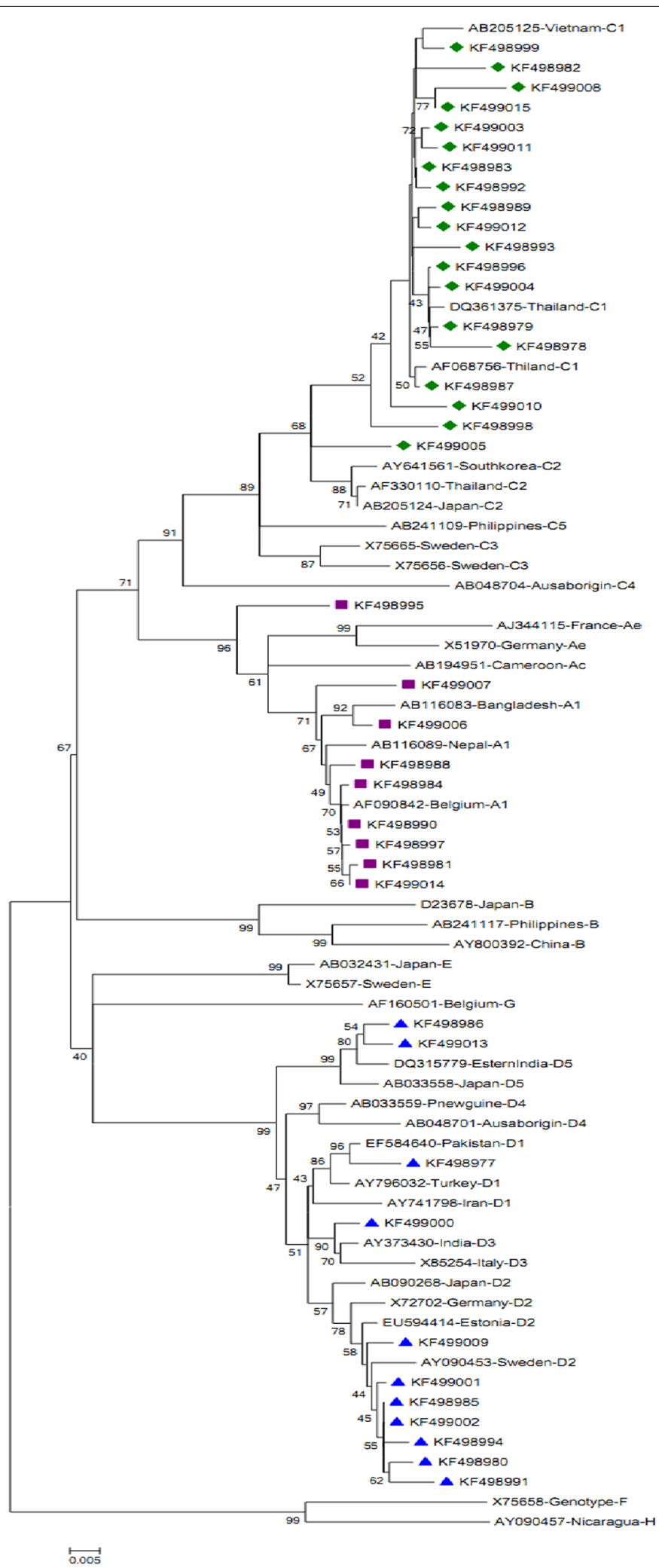

Fig. 2 Phylogenetic Tree. The tree is constructed using 950 bp nucleotide sequence (2908-643 bp of complete referance genome) of Pre-S1/PreS2/S region of HBV. Referance genome of genetypes A to H representing the standard HBV genotypes throughout the world were used for analysis (Additional file 2). Bootstrap values $(\geq 40)$ are indicated at the nodes of the brance 
Table 1 Distribution of genotypes and subgenotypes of $\mathrm{HBV}$ isolates

\begin{tabular}{llcl}
\hline Genotype & SubGenotype & Total & Percentage \\
\hline A & A1 & 9 & 23.1 \\
C & C1 & 19 & 48.7 \\
D & D1 & 1 & 2.5 \\
& D2 & 7 & 18 \\
& D3 & 1 & 2.5 \\
& D5 & 2 & 5.1 \\
A and C & & 2 & 5.1 \\
A and D & & 3 & 7.6 \\
\hline
\end{tabular}

Genotypes and subgenotypes were determined by phylogenetic tree, PCR system and NCBI genotyping tool

Table 2 Distribution of subtypes of HBV isolates (Additional file 4)

\begin{tabular}{lllll}
\hline Subtype & $\begin{array}{l}\text { Amino acids } \\
\text { at specific position }\end{array}$ & Total & Percentage & $\begin{array}{l}\text { Sub } \\
\text { genotypes }\end{array}$ \\
\hline adw2 & $122 \mathrm{~K}+127 \mathrm{P}+160 \mathrm{~K}$ & 11 & 28.2 & $\mathrm{~A} 1(8)$ \\
& & & & $\mathrm{C} 1(3)$ \\
ayw3 & $122 \mathrm{R}+127 \mathrm{~T}+160 \mathrm{~K}$ & 10 & 25.6 & $\mathrm{~A} 1(1)$ \\
& & & & $\mathrm{D} 5(2)$ \\
& & & & $\mathrm{D} 2(7)$ \\
adr & $122 \mathrm{~K}+127 \mathrm{P}+160 \mathrm{R}$ & 16 & 41 & $\mathrm{C} 1(16)$ \\
ayw2 & $122 \mathrm{R}+127 \mathrm{P}+140 \mathrm{~T}+12$ & 5.1 & $\mathrm{D} 1(1)$ \\
& $59 \mathrm{G}+160 \mathrm{~K}$ & & & $\mathrm{D} 3(1)$ \\
Total & & 39 & 100 &
\end{tabular}

The subtypes was determined by presence of specific amino acids at a paticular position as described in ref 5 and 7

genotypes C, D and A are circulating in the country. Similar results have been published from the 'Eastern India', close neighbor of Bangladesh, where in addition to genotype A and D, genotype C is prevalent (Datta et al. 2008a, b; Datta 2008). When the genotyping was done by PCR using type-specific primers, similar pattern of genotypes were found. Although some of the samples (11.76\%) contained mixture of genotypes; $\mathrm{A} / \mathrm{D}$ and $\mathrm{C} / \mathrm{D}$, indicating that PCR based genotype is more useful. This is also convenient and cost effective, but till now it only able to detect the genotypes A-F. The other genotypes (G, H, I and J) might be missed in this method, and so, it might not reveal the correct picture of HBV genotype distribution. On the other hand, the first two methods are unable to determine the multiple genotypes present in the same patient. However, we got approximately same result in three genotyping systems (without considering the mixed genotypes which found PCR based genotyping system).

Analysis of phylogenetic tree also revealed that genotype $C$ was found to be clustered only with the reference sequences of Vietnam and Thailand (Phung et al. 2010).
Genotype D and A showed different clustering pattern. In this study, genotype A was clustered with reference sequences from Japan, Pakistan, India, Turkey, Italy and Iran (Mohebbi et al. 2008), whereas, genotype D showed the different pattern of branch and was not only with Asian reference sequences but also with European references sequences. Prevalence of subgenotypes of above mentioned three genotypes were also determined. Genotype A $(23.1 \%)$ and C $(48.7 \%)$ were confined only within the sub-genotype $\mathrm{A} 1$ and $\mathrm{C} 1$ respectively. On the other hand, genotype D (28.2 \%) had different sub-genotype. These were D1 (2.5\%), D2 (18 \%), D3 (2.5) and D5 (5.1\%).

To determine the subtype, all of the nucleotide sequences were translated into amino acid sequences. We found that the prevalent subtypes were $a d r(41 \%)$, followed by adw2 (28.2 \%), ayw3 (25.6 \%) and ayw2 (5.1\%). The subtype $a d r$ completely restricted on genomic group C. However, the subtype $a d w 2$ found within the genotype $\mathrm{A}$ and $\mathrm{C}$. The subtype ayw were mostly found among the genotype $\mathrm{D}$.

Substitutions of amino acids in the surface protein were also well documented in our study. All of them were within the MHR of the S gene. Mutation at G145R (responsible for immune escape mutant), reported earlier (Waters et al. 1992) was observed in one of the cases (HBV-350 [GenBank: KF498986]). This mutation might be the cause of HBsAg negativity of that sample, although it gave PCR positive result. A number of other mutations on HBV S gene have also been reported (Bian et al. 2013; Avellon and Eschevarria 2006). A variation of S117I/N/ T/C/G was reported by Avellon and Eschevarria (2006). In our study, Serine in this position has been found to be replaced by Isoleucine in one case (HBV-532 [GenBank: KF498998]). Detail studies on the impact of HBV surface gene mutations on its structure and the course of pathogenesis could not performed.

Immunization program against $\mathrm{HBV}$ in Bangladesh have been started since 2004 (Rashid and Rafiq 2006). By this time the viruses might able to manage their structural changes to escape vaccination. However, people of Bangladesh are still not very conscious about HBV related liver infections. Though national immunization program has been launched only recently, however, post vaccination surveillance has not been started to confirm whether the vaccine worked properly or whether vaccinated children truly developed anti-HBV antibody. Therefore, a detailed study is essential with large number of sample volume to gather result about genotype, subtypes, subgenotypes and immune escape mutation rate of HBV in Bangladesh.

\section{Conclusion}

To know about the commonly found genotypic and subtypes of HBV in Bangladesh this article will give a clear 
idea, which is very important for both national and international virologist.

\section{Additional files}

Additional file 1. Type specific primers used to determine genotype A-F. Additional file 2. Accession numbers used as reference sequence. Additional file 3. Details information of the $39 \mathrm{HBV}$ isolates which were randomly selected from 50 PCR positive samples.

Additional file 4. Alignment of all proteins.

\section{Abbreviations}

HBV: hepatitis B virus; PCR: polymerase chain reaction; LC: liver cirrhosis; HCC: hepatocellular carcinoma; DNA: deoxy ribonucleic acid; RNA: ribonucleic acid; EIA: enzyme immune assay; HBsAg: hepatitis B surface antigen; HBeAg: HBe antigen; anti-HBe: HBe antibody; NCBI: National Center for Biotechnology Information; BLAST: basic local alignment search tool; bp: base pair; MHR: major hydrophilic region.

\section{Authors' contributions}

RA carried out the molecular studies, participated in the sequence alignment and drafted the manuscript; he also carried out in lab work data analysis and manipulations. HF had a great role in the initial lab work. AM, ACR, and NJ helped in collecting samples, providing patients information, and giving necessary advice during the study period. YM helped in collecting funds, study design and coordination of data analysis and manipulations and also helped to finalize draft manuscript. All authors read and approved the final manuscript.

\section{Author details}

${ }^{1}$ Department of Microbiology, University of Dhaka, Dhaka 1000, Bangladesh. ${ }^{2}$ Department of Biochemistry and Molecular Biology, University of Dhaka, Dhaka, Bangladesh. ${ }^{3}$ Department of Microbiology, Noakhali Science and Technology University, Sonapur, Noakhali 3814, Bangladesh.

\section{Acknowledgements}

We acknowledge Ministry of Science and Technology, GoB for providing research fund for this study. This study completed by partial financial support of the Ministry of Science and Technology, GoB.

\section{Competing interests}

The authors declare that they have no competing interests.

Received: 14 May 2015 Accepted: 15 February 2016

Published online: 05 March 2016

\section{References}

Acharya SK, Madan K, Dattagupta S, Panda SK (2006) Viral hepatitis in India. Natl Med J India 19(4):203-217

Alvarado Mora MV, Romano CM, Gomes-Gouvêa MS, Gutierrez MF, Botelho L, Carrilho FJ, Pinho JR (2011) Molecular characterization of the hepatitis $B$ virus genotypes in Colombia: a Bayesian inference on the genotype $F$. Infect Genet Evol 11(1):103-108

Avellon A, Eschevarria JM (2006) Frequency of Hepatitis B virus'a' determinant variants in unselected Spannish cheronic carriers. J Med Virol 78:24-36

Bian T, Yan H, Shen L, Wang F, Zhang S, Cao Y, Zhang S, Zhang Y, Bi S (2013) Change in Hepatitis $B$ virus large surace antigen variant prevalence 13 years after implementation of universal vaccine program in China. J Virol 87(22):12196-12206

Burland TG (2000) DNASTAR's Lasergene sequence analysis software. Methods Mol Biol 132:71-91
Buti M, Rodriguez-Frias F, Jardi R, Esteban R (2005) Hepatitis B virus genome variability and disease progression: the impact of pre-core mutants and HBV genotypes. J Clin Virol 34:S79-S82

Cao GW (2009) Clinical relevance and public health significance of hepatitis B virus genomic variations. World J Gastroenterol 15(46):5761-5769

Datta S (2008) An overview of molecular epidemiology of hepatitis B virus (HBV) in India. Virol J 5:156

Datta S, Biswas A, Chandra PK, Banerjee A, Panigrahi R, Mahapatra PK, ChaKrabarti S, Panda CK, Chakravarti R (2008a) Molecular epidemiology and clinical significance of hepatitis B virus genotypes, core promoter and precore mutations in eastern India. Intervirology 51(4):275-284

Datta S, Banerjee A, Chandra PK, Biswas A, Panigrahi R, Mahapatra PK, Chakrabarti S, Panda CK, Chakravarty R (2008b) Analysis of hepatitis B virus X gene phylogeny, genetic variability and its impact on pathogenesis: implications in Eastern Indian HBV carriers. Virology 382(2):190-198

Devesa M, Loureiro CL, Rivas Y, Monsalve F, Cardona N, Duarte MC, Poblete F, Guterrz MF, Botto C, Pujol FH (2008) Subgenotype diversity of hepatitis $B$ virus American genotype $F$ in Amerindians from Venezuela and the general population of Colombia. J Med Virol 80(1):20-26

Hall TA (1999) BioEdit: a user-friendly biological sequence alignment editor and analysis program for Windows 95/98/NT. In: Nucleic acid symposium series, vol 41. Oxford University Press, pp 95-98

Huy TT, Ushijima H, Win KM, Luengrojanakul P, Shrestha PK, Zhong ZH, Smirnov AV, Taltavull TC, Sata T, Abe K (2003) High prevalence of hepatitis B virus pre-S mutant in countries where it is endemic and its relationship with Genotype and Chronicity. J Clin Microbiol 41(12):5449-5455

Kao JH, Chen DS (2006) HBV genotypes: epidemiology and implications regarding natural history. Curr Hepat Rep 5:5-13

Kramvis A, Restorp K, Norder H, Botha JF, Magnius LO, Kew MC (2005) Full genome analysis of hepatitis $B$ virus genotype $E$ strains from SouthWestern Africa and Madagascar reveals low genetic variability. J Med Virol 77(1):47-52

Larkin MA, Blackshields G, Brown NP, Chenna R, McGettigan PA, McWilliam H, Valentin F, Wallace IM, Wilm A, Lopez R, Thompson JD, Gibson TJ, Higgins DG (2007) Clustal W and Clustal X version 2.0. Bioinformatics 23(21):2947-2948

Lee WM (1997) Hepatitis B virus infection. N Engl J Med 337:1733-1745

Magnius LO, Norder H (1995) Subtypes, genotypes and molecular epidemiology of the hepatitis $B$ virus as reflected by sequence variability of the S-gene. Intervirology 38(1-2):24-34

Mohebbi SR, Amini-Bavil-Olyaee S, Zali N, Noorinayer B, Derakhshan F, Chiani M, Rostami Nejad M, Antikchi MH, Sabahi F, Zali MR (2008) Molecular epidemiology of hepatitis B virus in Iran. Clin Microbiol Infect 14(9):858-866

Mulders MN, Venard V, Njayou M, Edorh AP, Bola Oyefolu AO, Kehinde MO, Muyembe TJJ, Nebie YK, Maiga I, Ammerlaan W, Fack F, Omilabu SA, Le Faou A, Muller CP (2004) Low genetic diversity despite hyperendemic ity of hepatitis B virus genotype E throughout West Africa. J Infect Dis 190(2):400-408

Naito H, Hayashi S, Abe K (2001) Rapid and specific genotyping system for hepatitis B virus corresponding to six major genotypes by PCR using type-specific primers. J Clin Microbiol 39(1):362-364

Norder H, Hammas B, Lofdahl S, Courouce AM, Magnius LO (1992) Comparison of the amino acid sequences of nine different serotypes of hepatitis $B$ surface antigen and genomic classification of the corresponding hepatitis B virus strains. J Gen Virol 73(Pt 5):1201-1208

Norder H, Hammas B, Lee SD, Bile K, Courouce AM, Mushahwar IK, Magnius LO (1993) Genetic relatedness of hepatitis B viral strains of diverse geographical origin and natural variations in the primary structure of the surface antigen. J Gen Virol 74:1341-1348

Olinger CM, Jutavijittum P, Hübschen JM, Yousukh A, Samountry B, Thammavong T, Toriyama K, Muller CP (2008) Possible new hepatitis B virus genotype, southeast Asia. Emerg Infect Dis 14(11):1777-1780

Phung TB, Alestig E, NguyenTL Hannoun C, Lindh M (2010) Genotype $X / C$ recombinant (putative genotype $I$ ) of hepatitis $B$ virus is rare in Hanoi, Vietnam - genotypes B4 and C1 predominate. J Med Virol 82(8):1327-1333

Rahman MT, Sultana R, Chowdhury SR (2007) Seropositivity and pattern of viral hepatitis in clinically suspected cases of hepatitis in Dhaka city. Bangladesh Med Res Counc Bul 33(3):103-106

Rashid H, Rafiq SM (2006) Hepatitis B vaccination in Bangladesh: a suggestion based on current evidence. Hepat Mon 6(1):41-44 
Reuman EC, Margeridon-Thermet S, Caudill HB, Liu T, Borroto-Esoda K, Svarovskaia ES, Holmes SP, Shafer RW (2010) A classification model for G-to-A hypermutation in hepatitis B virus ultra-deep pyrosequencing reads. Bioinformatics 26(23):2929-2932

Schaefer S (2007) Hepatitis B virus taxonomy and hepatitis B virus genotypes. World J Gastroenterol 13(1):14-21

Shi YH (2012) Correlation between hepatitis B virus genotypes and clinical outcomes. Jpn J Infect Dis 65(6):476-482

Singh J, Dickens C, Pahal V, Kumar R, Chaudhary R, Kramvis A, Kew MC (2009) First report of genotype e of hepatitis $B$ virus in an Indian population. Intervirology 52(5):235-238

Tamura K, Dudley J, Nei M, Kumar S (2007) MEGA4: molecular evolutionary genetics analysis (MEGA) software version 4.0. Mol Biol Evol 24(8):1596-1599

Tanwar S, Dusheiko G (2012) Is there any value to hepatitis B virus genotype analysis? Curr Gastroenterol Rep 14(1):37-46

Tatematsu K, Tanaka Y, Kurbanov F, Sugauchi F, Mano S, Maeshiro T, Nakayoshi T, Wakuta M, Miyakawa Y, Mizokami M (2009) A genetic variant of hepatitis B virus divergent from known human and ape genotypes isolated from a Japanese patient and provisionally assigned to new genotype. J. J Virol 83:10538-10547

Waters JA, Kennedy M, Voet P, Hauser P, Petre J, Carman W, Thomas HC (1992) Loss of the common "a" determinant of hepatitis B surface antigen by a vaccine-induced escape mutant. J Clin Invest 90(6):2543-2547

WHO (2008) Hepatitis B. World Health Organization Fact Sheet, No. 204

Yang HI, Yeh SH, Chen PJ, Chen PJ, Iloeje UH, Jen CL, Su J, Wang LY, Lu SN, You SL, Chen DS, Liaw YF, Chen CJ (2008) Associations between hepatitis B virus genotype and mutants and the risk of hepatocellular carcinoma. J Natl Cancer Inst 100:1134-1143

Yu H, Yuan Q, Ge SX, Wang HY, Zhang YL, Chen QR, Zhang J, Chen PJ, Xia NS (2010) Molecular and phylogenetic analyses suggest an additional hepatitis B virus genotype "I". PLoS One 5(2):e9297

Zaki MH, Darmstadt GL, Baten A, Ahsan CR, Saha SK (2003) Seroepidemiology of Hepatitis B and Delta Virus Infections in Bangladesh. J Trop Pediatr 49(6):371-374

\section{Submit your manuscript to a SpringerOpen ${ }^{\odot}$ journal and benefit from:}

- Convenient online submission

- Rigorous peer review

- Immediate publication on acceptance

- Open access: articles freely available online

- High visibility within the field

- Retaining the copyright to your article

Submit your next manuscript at $\downarrow$ springeropen.com 